\title{
Unexpected emphysematous cystitis and pyelitis
}

\author{
M Margarida Robalo (1) , 1,2 M Manuel Lopes, ${ }^{2,3}$ M Carolina Monteiro ${ }^{2,3}$
}

'Department of Internal Medicine, Hospital de Braga, Braga, Portugal

${ }^{2}$ Palliative Care Unit, CUF Porto, Porto, Portugal

${ }^{3}$ Oncology Department, CUF Porto, Porto, Portugal

\section{Correspondence to}

Dr M Margarida Robalo;

mmargaridarobalo@gmail.com

Accepted 19 February 2020

\section{DESCRIPTION}

A 69-year-old man with a recently diagnosed lung cancer with bone metastasis presented with a 2-week history of progressive weakness and confusion. The patient initially attributed the symptoms to the start of opioid therapy due to generalised pain. He was submitted to chemotherapy 4 days before admission and there were no relevant analytical changes, although there was no clinical improvement. Despite opioid rotation and pain control, there was a clinical worsening to a lethargic status. Besides severe psychomotor retardation, the patient was admitted with a subfebrile temperature, hypotension, tachycardia, decreased urinary output and global abdominal tenderness. Blood analysis revealed an important elevation of inflammatory markers (serum white blood count $13000 / \mu \mathrm{L}$; C reactive protein $32.4 \mathrm{mg} / \mathrm{dL}$ ) as well as an acute kidney injury (blood urea nitrogen $105 \mathrm{mg} / \mathrm{dL}$; plasmatic creatinine $2.6 \mathrm{mg} / \mathrm{dL}$ ). An abdominal CT was

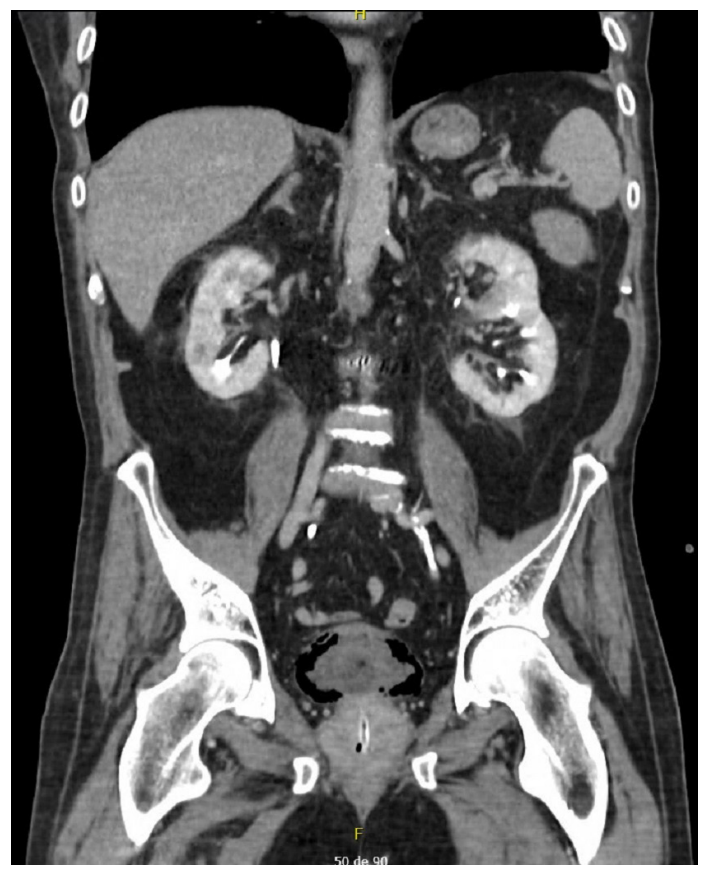

Figure 1 Emphysematous cystitis and left emphysematous pyelitis.

\section{Learning points}

- Emphysematous cystitis is a rare urinary tract infection more commonly seen in immunocompromised patients, usually with non-specific symptoms that can be masked with medication.

- Failure to recognise or diagnose this condition early in the course of the infection increases the associated mortality rate.

- A complete clinical evaluation and high suspicion are needed to establish an early treatment and prevent the evolution of septic shock and death.

performed and showed intramural gas dissecting the bladder wall with extension to the left kidney (figure 1), findings consistent with emphysematous cystitis and pyelonephritis. Broad-spectrum antibiotherapy with intravenous meropenem was started after blood and urine cultures were obtained. After 3 days, Klebsiella pneumoniae, sensitive to meropenem, grew in the urine culture, but haemocultures were negative. Despite the antibiotic treatment and consequent improvement of inflammatory markers, the patient developed severe neutropenia (absolute neutrophil count 40/ $\mu \mathrm{L}$ ), most likely related to chemotherapy, with no response to granulocyte-colony stimulating factor therapy. There was an adverse clinical evolution and the patient died from septic shock 10 days after admission.

Contributors MMR: collected the clinical data and wrote the description of the attached 'Image in...'. CM and MML: revised the manuscript and approved it for publication. All the authors contributed to the management of the reported clinical case.

Funding The authors have not declared a specific grant for this research from any funding agency in the public, commercial or not-for-profit sectors.

Competing interests None declared.

Patient consent for publication Next of kin consent obtained.

Provenance and peer review Not commissioned; externally peer reviewed.

ORCID iD

M Margarida Robalo http://orcid.org/0000-0003-1335-9437 
Copyright 2020 BMJ Publishing Group. All rights reserved. For permission to reuse any of this content visit https://www.bmj.com/company/products-services/rights-and-licensing/permissions/

BMJ Case Report Fellows may re-use this article for personal use and teaching without any further permission.

Become a Fellow of BMJ Case Reports today and you can:

- Submit as many cases as you like

Enjoy fast sympathetic peer review and rapid publication of accepted articles

Access all the published articles

Re-use any of the published material for personal use and teaching without further permission

Customer Service

If you have any further queries about your subscription, please contact our customer services team on +44 (0) 2071111105 or via email at support@bmj.com.

Visit casereports.bmj.com for more articles like this and to become a Fellow 